\title{
Pewarisan Sifat Ketahanan Hidup dan Karakter Fenotipik Melon (Cucumis melo L. "TALITA" \& "TANIA") Hasil Persilangan Backcross dan Testcross Induk Tacapa Pada Kondisi Karst Secara In-Vivo
}

\author{
GANIES RIZA ARISTYA ${ }^{1}$, ROVIQO ARIFIYANTI ${ }^{1}$, AZIIMATUR RIF'AH $^{1}$ \\ ${ }^{1}$ Laboratorium Genetika, Fakultas Biologi, Universitas Gadjah Mada \\ Jl. Teknika Selatan Sekip Utara Sleman Yogyakarta 55281 \\ email: ganies_riza@ugm.ac.id
}

\begin{abstract}
Melon (Cucumis melo L.) is one of the fruits commodity priorities and require more attention. Plant breeding efforts led to improved varieties like TACAPA .TACAPA is a new melon cultivar derived from crosses between $\rightarrow$ PI and $\delta$ Action with cross test PI. Since 2012, superior melon reassembled from crosses between $q$ TACAPA and $\delta$ PI become TANIA and $q$ TACAPA and $\delta$ Action become TALITA which projection can growth in critical lands karst. The objective of this research was to know ability to grow and morphological characteristics TALITA and TANIA melons were tested to determine nutrient levels of $\mathrm{CaCO}_{3}$. This research started from a field survey conducted in Hills of Mountain Sewu, South Mountain hills Sentolo Kulon Progo, and Dlingo Bantul, Yogyakarta.Melons grown on soil with fertilizer mixed media which further watering treated $\mathrm{CaCO}_{3}$ solution with a concentration of $0.5 \%, 1 \%, 3 \%, 4 \%$, and $5 \%$. Observations were made until the time of harvest ( \pm 10 weeks). TANIAand TALITA melon could grow on critical lands karst compared with parental. TANIA melonfruits have a weight, round, D - horizontal, D - vertical lower than two parental. TALITA melon fruits have a weight, D-horizontal higher than two parental, and D-vertical is lower than two parental.
\end{abstract}

Keywords: critical land karst, Cucumis melo L., TALITA, TANIA

\section{PENDAHULUAN}

Buah melon, merupakan tanaman holtikultura dari familia Cucurbitaceae yang sangat digemari masyarakat karena mempunyai keunggulan pada rasanya yang manis, tektsur daging buah yang renyah, warna daging buah yang bervariasi, dan mempunyai aroma yang khas. Komoditas ini juga mempunyai nilai ekonomi dan prospek yang menjanjikan, baik dalam pemasaran buah maupun benihnya. Kebutuhan terhadap tanaman buah-buahan meningkat seiring dengan meningkatnya kesadaran masyarakat akan gizi. Melon (Cucumis melo L.) merupakan salah satu komoditas buah-buahan yang menjadi prioritas dan memerlukan perhatian lebih.

Usaha budidaya melon memiliki prospek cukup besar dilihat dari potensi lahan dan permintaan pasar yang terus meningkat. Di tengah tingginya permintaan pasar, timbul permasalahan yaitu terbatasnya buah yang tersedia di pasaran. Hal ini disebakan terbatasnya sentra penanaman buah melon. Popularitas melon di Indonesia harus diimbangi dengan produksi dan kualitas buah yang tinggi. Faktor lingkungan sangat berpengaruh terhadap pertumbuhan dan hasil tanaman melon. Perbedaan ketinggian dan kondisi lahan pada masing-masing daerah menyebabkan tidak semua daerah cocok untuk ditanami melon. Meskipun demikian, tidak semua lahan yang cocok ditanami melon menghasilkan melon dengan kualitas tinggi. Metode pemulian tanaman, diharapkan mampu menghasilkan melon yang lebih unggul, bervariasi dan menarik minat konsumen serta seragam akan hasil yang diperoleh.

Lahan kritis dapat disebabkan karena hilangnya unsur hara di dalamnya, komposisi unsur penyusun lahan, dan dapat disebabkan karena kondisi alam.Kerugian akibat lahan kritis di Indonesia cukup besar, diperkirakan mencapai 10 triliun/tahun (Karama \& Abdurachman, 1995). Provinsi DIY, 
mempunyai areal seluas 318.560 ha (Badan Litbang Pertanian, 1997) dan sebagian besar berupa lahan pertanian.

Pada penelitian ini digunakan melon hasil persilangan backcross TACAPA (TANIA) dan testcross (TALITA). TACAPA merupakan hasil persilangan antara PI 171795 dan Action dengan test cross PI (Aristya, 2009). Sementara itu, melon TANIA didapatkan dari hasil perakitan induk $O$ TACAPA $x \widehat{\jmath}$ PI dan TALITA dari induk $q$ TACAPA $x \hat{\sigma}$ Action (Agriansyah, 2013). Melon varietas ini digunakan karena memilki keunggulan melon mampu ditanam pada kondisi cuaca yang tidak menentu (dapat ditanam pada musim hujan maupun kemarau) (Aristya, 2012). Tujuan dari penelitian ini adalah untuk mengetahui kemampuan tumbuhn melon TANIA dan TALITA pada kondisi tercekam yaitu di lahan karst (kapur) dan mengetahui karakter fenotip dari buah hasil budidayan secara in-vivo.

\section{METODE}

Survei lapangan. Survei lapangan dilakukan untuk mengetahui kondisi lapangan sehingga mempermudah dalam penentuan layout dan pelaksanaan penelitian. Survei lapangan dilakukan di Perbukitan Sewu, Gunung Kidul Perbukitan Sentolo Kulon Progo, dan Dlingo Bantul, Yogyakarta untuk mengetahui kadar kekritisan lahan.

Persiapan Bibit Melon. Media yang digunakan dalam penelitian ini adalah tanah dan pupuk kompos atau kascing.Tanah dan pupuk kompos atau kascing selanjutnya dicampur dalam ember. Bibit melon yang akan ditanam disiapkan. Bibit melon yang digunakan disemaikan terlebih dahulu. Penyemaian bibit melon dilakukan dengan meletakkan biji melon di atas nampan yang telah dialasi koran yang dibasahi dengan air. Setelah biji bekecambah, dipindahkan masingmasing ke dalam polybag kecil yang telah berisi tanah.Kemudian benih melon tersebut diletakkan di tempat yang teduh.

Penanaman. Bibit melon yang telah disiapkan sebelumnya ditanam di dalam ember yang berisi campuran tanah dan pupuk kompos atau kascing.Dalam satu ember berisi tiga bibit melon yang jaraknya diatur agar tidak saling berdempetan. Pada tiap-tiap ember diberi kode yang berisi tulisan varietas melon dan konsentrasi perlakuan yang akan diberikan.

Penyiraman dan Pemupukan. Setelah bibit melon ditanam, dilakukan penyiraman dan pemupukan secara teratur selama dua bulan.Penyiraman dilakukan setiap hari saat pagi hari sekitar pukul 07.00-09.00 WIB.Sedangkan pemupukan dilakukan minimal seminggu dua kali.Pupuk yang digunakan pada bibit melon yang telah tumbuh yaitu pupuk NPK.

Pengamatan. Parameter yang diamati adalah curamnya tebing dari lahan yang digunakan sebagai media menggunakan clinometer. Selain itu kadar karbonat atau kapur dari tanah tersebut diukur melalui uji ilmu hara. Uji hara dilakukan dengan Perangkat Uji Tanah Kering (PUTK). Melon yang telah ditanam dalam media yang telah disiapkan sebelumnya kemudian diberikan perlakuan penambahan $\mathrm{CaCO}_{3}$ dengan konsentrasi $0.1 \% ; 1 \% ; 3 \% ; 4 \% ; 5 \%$ dengan cara menyiramkannya 2 hari sekali sesuai dengan kode yang tertera pada ember.

Analisis Data Pasca Panen. Pada saat penanaman data yang diamati meliputi tinggi tanaman, jumlah daun, jumlah bunga jantan, jumlah bunga betina, dan jumlah bunga lengkap.Sedangkan data yang diambil pasca panen meliputi berat basah buah, keliling buah, diameter horizontal buah, diameter vertikal buah, dan berat kering tanaman.

Analisis Data. Setelah data diperoleh, data diolah dalam bentuk diagram dan ANAVA dengan menggunakan program SPSS versi 15.

\section{HASIL}

Pada penelitian ini, dilakukan survey di tiga lokasi lahan kritis karst di DI Yogyakarta, meliputi lahan karst perbukitan Gunung Sewu, Kabupaten Gunung Kidul; lahan kritis karst Perbukitan Sentolo, Kabupaten Kulon Progo; lahan kritis karst Perbukitan Dlingo, Kabupaten Bantul. Dari ketiga lokasi tesebut masing-masing diambil sampel tanah yang kemudian diuji kadar $\mathrm{CaCO}_{3}$ nya. Pengujian kadar $\mathrm{CaCO}_{3}$ inilah yang menjadi dasar penentuan konsentrasi perlakuan kapur yang 
diberikan pada tanaman melon nantinya.

koordinat pengambilan sampel didapatkan Berdasarkan uji kadar $\mathrm{CaCO}_{3}$ dan letak data Tabel 1.

Tabel 1. Hasil uji kadar $\mathrm{CaCO}_{3}$ dan letak koordinat pengambilan sampel

\begin{tabular}{|c|c|c|c|}
\hline Sampel tanah & Titik koordinat \& elevasi & Kadar & Dokumentasi \\
\hline Dlingo & $\begin{array}{l}\text { BT : } 110^{\circ} 27^{\prime}, 56.2^{\prime \prime} \\
\text { LS : } 07^{\circ} 55^{\prime} 58.7^{\prime \prime} \\
\text { Elevasi : } 230\end{array}$ & $0.85 \%$ & \\
\hline Sentolo & $\begin{array}{l}\text { BT : } 110^{\circ} 11^{\prime} 11.3^{\prime \prime} \\
\text { LS : } 07^{\circ} 49^{\prime} 56.5^{\prime \prime} \\
\text { Elevasi : } 116\end{array}$ & $3.195 \%$ & \\
\hline Gunung Sewu & $\begin{array}{l}\text { BT : } 08^{\circ} 03^{\prime} 36.7^{\prime \prime} \\
\text { LS : } 110^{\circ} 32^{\prime} 15.7 \text { “ } \\
\text { Elevasi : } 265\end{array}$ & $4.32 \%$ & \\
\hline
\end{tabular}

Untuk mengetahui ketahanan hidup tanaman melon backcross TACAPA terhadap kondisi lahan kritis karst, tanaman diamati pertumbuhannya selama 10 minggu. Parameter pertumbuhan tanaman melon yang diamati selama 10 hari meliputi tinggi tanaman melon, jumlah daun tanaman melon, jumlah bunga jantan tanaman melon, jumlah bunga betina tanaman melon, dan jumlah bunga lengkap tanaman melon. Masing-masing parameter pertumbuhan tersebut kemudian dianalisis dengan ANOVA menggunakan program SPSS versi 15.Data hasil analisis ANOVA disajikan dalam Tabel 2.

Tabel 2. Hasil ANOVA jumlah daun, tinggi tanaman melon, jumlah bunga jantan, jumlah bunga betina, jumlah bunga lengkap

\begin{tabular}{|c|c|c|c|c|c|c|c|c|c|}
\hline \multirow{3}{*}{\multicolumn{2}{|c|}{ Perlakuan }} & \multirow{3}{*}{$\mathrm{N}$} & \multicolumn{2}{|c|}{ Subsets for alpha $=.05$} & \multirow{3}{*}{ Perlakuan } & \multirow{3}{*}{$\mathrm{N}$} & \multicolumn{3}{|c|}{ Subsets for alpha $=.05$} \\
\hline & & & Tinggi & $\begin{array}{c}\text { Jumlah } \\
\text { daun }\end{array}$ & & & \multirow{2}{*}{$\begin{array}{c}\text { Bunga } \\
\text { jantan } \\
1\end{array}$} & \multirow{2}{*}{$\begin{array}{c}\text { Bunga } \\
\text { Betina } \\
1\end{array}$} & \multirow{2}{*}{$\begin{array}{c}\begin{array}{c}\text { Bunga } \\
\text { lengkap }\end{array} \\
1\end{array}$} \\
\hline & & & 1 & 1 & & & & & \\
\hline \multirow[t]{8}{*}{$\begin{array}{l}\text { Duncan } \\
\mathrm{a}\end{array}$} & $\mathrm{P} 0 \%$ & 10 & $110.0250^{\mathrm{a}}$ & $11.2000^{\mathrm{b}}$ & $\begin{array}{c}\text { Duncan } \\
\mathrm{a}\end{array}$ & 4 & $0.0000^{\mathrm{c}}$ & $0.0000^{\mathrm{d}}$ & $4.7500^{\mathrm{e}}$ \\
\hline & $\mathrm{A} 0 \%$ & 10 & $117.2000^{\mathrm{a}}$ & $13.6000^{\mathrm{b}}$ & $\mathrm{A} 0 \%$ & 4 & $3.7500^{c}$ & $0.7500^{\mathrm{d}}$ & $2.2500^{\mathrm{e}}$ \\
\hline & $\begin{array}{l}\text { Tania0 } \\
\%\end{array}$ & 10 & $87.4250^{\mathrm{a}}$ & $12.0000^{\mathrm{b}}$ & $\begin{array}{c}\text { Tania } \\
0 \%\end{array}$ & 4 & $0.0000^{\mathrm{c}}$ & $0.2500^{\mathrm{d}}$ & $2.7500^{\mathrm{e}}$ \\
\hline & $\mathrm{P} 0 \%$ & 10 & & $103.830^{\mathrm{g}}$ & $\mathrm{P} 0 \%$ & 4 & $4.7500^{\mathrm{a}}$ & $0.0000^{\mathrm{b}}$ & $0.0000^{\mathrm{c}}$ \\
\hline & $\mathrm{A} 0 \%$ & 10 & $10.900^{\mathrm{def}}$ & $84.960^{\mathrm{g}}$ & $\mathrm{A} 0 \%$ & 4 & $2.2500^{\mathrm{a}}$ & $1.0000^{\mathrm{b}}$ & $0.7500^{\mathrm{c}}$ \\
\hline & $\begin{array}{l}\text { Talita0 } \\
\%\end{array}$ & 10 & $9.900 \mathrm{def}$ & $62.725^{\mathrm{g}}$ & $\begin{array}{c}\text { Talita } \\
0 \%\end{array}$ & 4 & $0.2500^{\mathrm{a}}$ & $1.0000^{\mathrm{b}}$ & $0.5000^{\mathrm{c}}$ \\
\hline & $\mathrm{P} 0.5 \%$ & 10 & $62.3250^{\mathrm{a}}$ & $9.4000^{\mathrm{b}}$ & $\begin{array}{c}\mathrm{P} 0.5 \\
\%\end{array}$ & 4 & $1.7500^{\mathrm{c}}$ & $0.7500^{\mathrm{d}}$ & $2.2500^{\mathrm{e}}$ \\
\hline & $\mathrm{A} 0.5 \%$ & 10 & $80.2250^{\mathrm{a}}$ & $9.5500^{\mathrm{b}}$ & $\begin{array}{c}\mathrm{A} 0.5 \\
\%\end{array}$ & 4 & $2.1667^{\mathrm{c}}$ & $1.2500^{\mathrm{d}}$ & $3.0000^{\mathrm{e}}$ \\
\hline
\end{tabular}




\begin{tabular}{|c|c|c|c|c|c|c|c|c|}
\hline $\begin{array}{l}\text { Tania0. } \\
5 \%\end{array}$ & 10 & $62.4250^{\mathrm{a}}$ & $7.1000^{\mathrm{b}}$ & $\begin{array}{l}\text { Tania } \\
0.5 \%\end{array}$ & 4 & $1.7500^{\mathrm{c}}$ & $0.6250^{\mathrm{d}}$ & $2.7500^{\mathrm{e}}$ \\
\hline & & & & P0.5 & & & & \\
\hline $\mathrm{P} 0.5 \%$ & 10 & $100.725^{\mathrm{g}}$ & & $\%$ & 4 & $1.7500^{\mathrm{a}}$ & $4.0000^{\mathrm{b}}$ & $0.7500^{\mathrm{c}}$ \\
\hline & & & & A0.5 & & & & \\
\hline A $0.5 \%$ & 10 & $68.350^{\mathrm{g}}$ & $10.400^{\mathrm{def}}$ & $\%$ & 4 & $3.5000^{\mathrm{a}}$ & $2.5000^{\mathrm{b}}$ & $1.2500^{\mathrm{c}}$ \\
\hline $\begin{array}{l}\text { Talita } 0 . \\
5 \%\end{array}$ & 10 & $87.100^{\mathrm{g}}$ & $7.350^{\mathrm{def}}$ & $\begin{array}{l}\text { Talita } \\
0.5 \% \\
\end{array}$ & 4 & $1.0000^{\mathrm{a}}$ & $1.6250^{\mathrm{b}}$ & $0.6250^{\mathrm{c}}$ \\
\hline $\mathrm{P} 1 \%$ & 10 & $90.4000^{\mathrm{a}}$ & $9.1500^{\mathrm{b}}$ & $\mathrm{P} 1 \%$ & 4 & $0.2500^{\mathrm{c}}$ & $0.0000^{\mathrm{d}}$ & $1.5000^{\mathrm{e}}$ \\
\hline $\mathrm{A} 1 \%$ & 10 & $87.0750^{\mathrm{a}}$ & $10.8000^{\mathrm{b}}$ & $\mathrm{A} 1 \%$ & 4 & $0.0000^{c}$ & $0.7500^{\mathrm{d}}$ & $3.5000^{\mathrm{e}}$ \\
\hline $\begin{array}{l}\text { Tania1 } \\
\%\end{array}$ & 10 & $80.7750^{\mathrm{a}}$ & $8.8500^{\mathrm{b}}$ & $\begin{array}{c}\text { Tania } \\
1 \%\end{array}$ & 4 & $2.0000^{\mathrm{c}}$ & $0.2500^{\mathrm{d}}$ & $1.2500^{\mathrm{e}}$ \\
\hline $\mathrm{P} 1 \%$ & 10 & $110.700^{\mathrm{g}}$ & & $\mathrm{P} 1 \%$ & 4 & $2.2500^{\mathrm{a}}$ & $0.7500^{\mathrm{b}}$ & $0.0000^{\mathrm{c}}$ \\
\hline $\mathrm{A} 1 \%$ & 10 & $75.825^{\mathrm{g}}$ & $11.225^{\mathrm{def}}$ & $\mathrm{A} 1 \%$ & 4 & $3.5000^{\mathrm{a}}$ & $1.2500^{\mathrm{b}}$ & $0.7500^{\mathrm{c}}$ \\
\hline $\begin{array}{l}\text { Talita } 1 \\
\%\end{array}$ & 10 & $92.400^{\mathrm{g}}$ & $7.450^{\mathrm{def}}$ & $\begin{array}{c}\text { Talita } \\
1 \% \\
\end{array}$ & 4 & $2.0000^{\mathrm{a}}$ & $1.8750^{\mathrm{b}}$ & $0.6250^{\mathrm{c}}$ \\
\hline P3\% & 10 & $107.9750^{\mathrm{a}}$ & $13.2500^{\mathrm{b}}$ & P3\% & 4 & $2.5000^{c}$ & $0.7500^{\mathrm{d}}$ & $1.7500^{\mathrm{e}}$ \\
\hline A3\% & 10 & $86.0400^{\mathrm{a}}$ & $13.0500^{\mathrm{b}}$ & A $3 \%$ & 4 & $2.2500^{\mathrm{c}}$ & $0.6250^{\mathrm{d}}$ & $0.7500^{\mathrm{e}}$ \\
\hline $\begin{array}{l}\text { Tania3 } \\
\% \\
\end{array}$ & 10 & $85.9000^{\mathrm{a}}$ & $10.7500^{\mathrm{b}}$ & $\begin{array}{c}\text { Tania } \\
3 \% \\
\end{array}$ & 4 & $0.6250^{\mathrm{c}}$ & $0.0000^{\mathrm{d}}$ & $2.7500^{\mathrm{e}}$ \\
\hline P3\% & 10 & $79.790^{\mathrm{g}}$ & & P3\% & 4 & $2.0000^{\mathrm{a}}$ & $3.5000^{\mathrm{b}}$ & $0.7500^{\mathrm{c}}$ \\
\hline A $3 \%$ & 10 & $77.650^{\mathrm{g}}$ & $10.650^{\mathrm{def}}$ & A $3 \%$ & 4 & $2.0000^{\mathrm{a}}$ & $2.0000^{\mathrm{b}}$ & $0.6250^{\mathrm{c}}$ \\
\hline $\begin{array}{l}\text { Talita3 } \\
\%\end{array}$ & 10 & $82.375^{\mathrm{g}}$ & $8.500^{\text {def }}$ & $\begin{array}{c}\text { Talita } \\
3 \% \\
\end{array}$ & 4 & $1.7500^{\mathrm{a}}$ & $2.2500^{\mathrm{b}}$ & $1.0000^{\mathrm{c}}$ \\
\hline $\mathrm{P} 4 \%$ & 10 & $73.7500^{\mathrm{a}}$ & $10.4000^{\mathrm{b}}$ & $\mathrm{P} 4 \%$ & 4 & $2.5000^{c}$ & $0.0000^{\mathrm{d}}$ & $3.5000^{\mathrm{e}}$ \\
\hline $\mathrm{A} 4 \%$ & 10 & $81.800^{\mathrm{a}}$ & $10.6500^{\mathrm{b}}$ & $\mathrm{A} 4 \%$ & 4 & $2.0000^{\mathrm{c}}$ & $1.0000^{\mathrm{d}}$ & $2.0000^{\mathrm{e}}$ \\
\hline $\begin{array}{l}\text { Tania4 } \\
\%\end{array}$ & 10 & $79.9500^{\mathrm{a}}$ & $8.4000^{\mathrm{b}}$ & $\begin{array}{c}\text { Tania } \\
4 \% \\
\end{array}$ & 4 & $1.1250^{\mathrm{c}}$ & $0.2500^{\mathrm{d}}$ & $0.5000^{\mathrm{e}}$ \\
\hline $\mathrm{P} 4 \%$ & 10 & $81.750^{\mathrm{g}}$ & $12.000^{\mathrm{def}}$ & $\mathrm{P} 4 \%$ & 4 & $2.7500^{\mathrm{a}}$ & $0.2500^{\mathrm{b}}$ & $0.0000^{\mathrm{c}}$ \\
\hline $\mathrm{A} 4 \%$ & 10 & $68.750^{\mathrm{g}}$ & $8.050^{\mathrm{def}}$ & $\mathrm{A} 4 \%$ & 4 & $1.2500^{\mathrm{a}}$ & $2.0000^{\mathrm{b}}$ & $1.0000^{\mathrm{c}}$ \\
\hline $\begin{array}{l}\text { Talita4 } \\
\%\end{array}$ & 10 & $66.225^{\mathrm{g}}$ & $8.700^{\mathrm{def}}$ & $\begin{array}{c}\text { Talita } \\
4 \% \\
\end{array}$ & 4 & $0.2500^{\mathrm{a}}$ & $2.6250^{\mathrm{b}}$ & $0.7500^{\mathrm{c}}$ \\
\hline $\mathrm{P} 5 \%$ & 10 & $103.7250^{\mathrm{a}}$ & $11.7000^{\mathrm{b}}$ & P5\% & 4 & $3.5000^{c}$ & $0.2500^{\mathrm{d}}$ & $3.5000^{\mathrm{e}}$ \\
\hline $\mathrm{A} 5 \%$ & 10 & $76.7250^{\mathrm{a}}$ & $7.2000^{\mathrm{b}}$ & $\mathrm{A} 5 \%$ & 4 & $1.2500^{\mathrm{c}}$ & $0.2500^{\mathrm{d}}$ & $1.6250^{\mathrm{e}}$ \\
\hline $\begin{array}{l}\text { Tania5 } \\
\%\end{array}$ & 10 & $92.1750^{\mathrm{a}}$ & $12.0500^{\mathrm{b}}$ & $\begin{array}{c}\text { Tania } \\
5 \%\end{array}$ & 4 & $0.8750^{c}$ & $1.2500^{\mathrm{d}}$ & $1.0000^{\mathrm{e}}$ \\
\hline P5\% & 10 & $78.160^{\mathrm{g}}$ & & $\mathrm{P} 5 \%$ & 4 & $0.5000^{\mathrm{a}}$ & $1.5000^{\mathrm{b}}$ & $0.2500^{\mathrm{c}}$ \\
\hline $\mathrm{A} 5 \%$ & 10 & $89.510^{\mathrm{g}}$ & $11.100^{\mathrm{def}}$ & A $5 \%$ & 4 & $1.0000^{\mathrm{a}}$ & $2.2500^{\mathrm{b}}$ & $0.2500^{\mathrm{c}}$ \\
\hline $\begin{array}{l}\text { Talita5 } \\
\%\end{array}$ & 10 & $37.425^{\mathrm{g}}$ & $4.950^{\mathrm{def}}$ & $\begin{array}{c}\text { Talita } \\
5 \%\end{array}$ & 4 & $0.0000^{\mathrm{a}}$ & $0.0000^{\mathrm{b}}$ & $0.0000^{\mathrm{c}}$ \\
\hline Sig & & 0.195 & 0.105 & Sig & & 0.156 & 0.122 & 0.158 \\
\hline Sig & & 0.63 & 0.87 & Sig & & 0.07 & 0.184 & 416 \\
\hline
\end{tabular}

Angka yang diikuti huruf yang sama pada satu kolom menunjukkan bahwa tidak ada beda nyata berdasar uji lanjut BNT pada taraf nyata 5\%.

Pada penelitian ini selain dilakukan analisis data pertumbuhan tanaman melon, juga dilakukan analisis data pasca panen, meliputi berat buah tanaman melon, keliling buah tanaman melon, D-horizontal tanaman melon, D-vertikal tanaman melon, dan berat kering tanaman melon yang disajikan dalam bentuk grafik. 


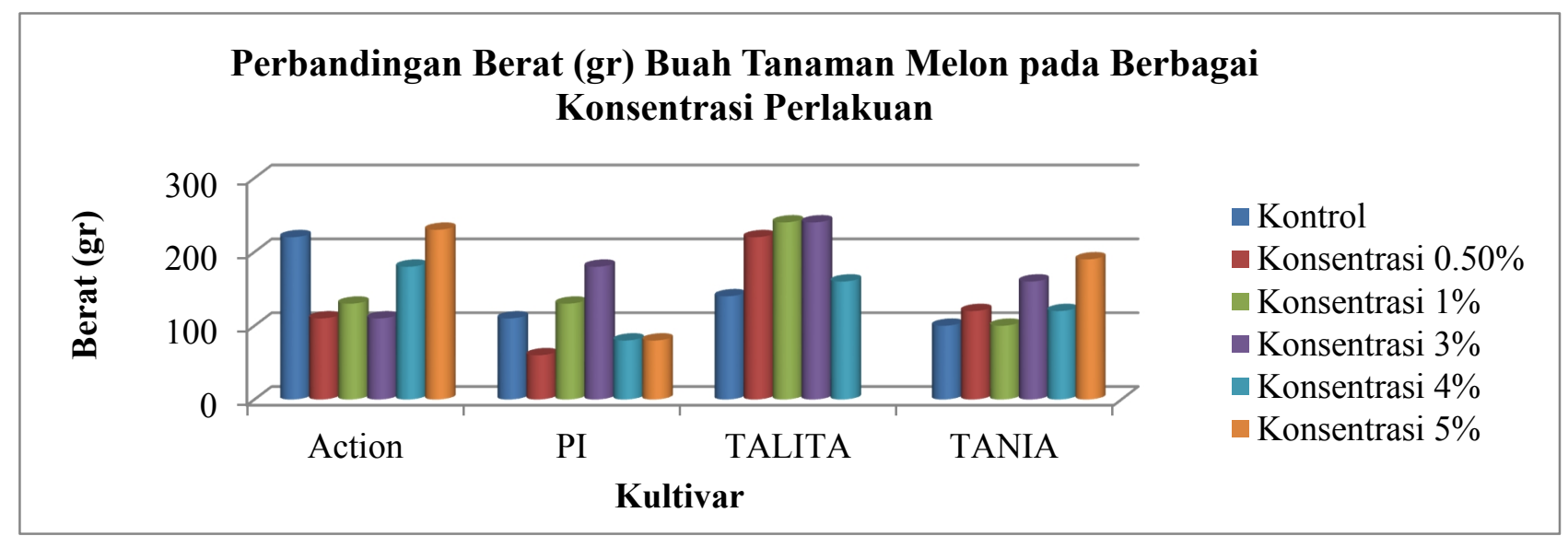

Gambar 1. Grafik perbandingan berat buah melon TANIA dan TALITA

Dari Gambar 1 dapat dilihat bahwa berat buah melon TANIA lebih rendah dibanding dengan berat kedua indukannya yaitu indukan
Action dan PI. Sedangkan berat buah melon TALITA lebih tinggi dari kedua indukannya yaitu Action dan PI.

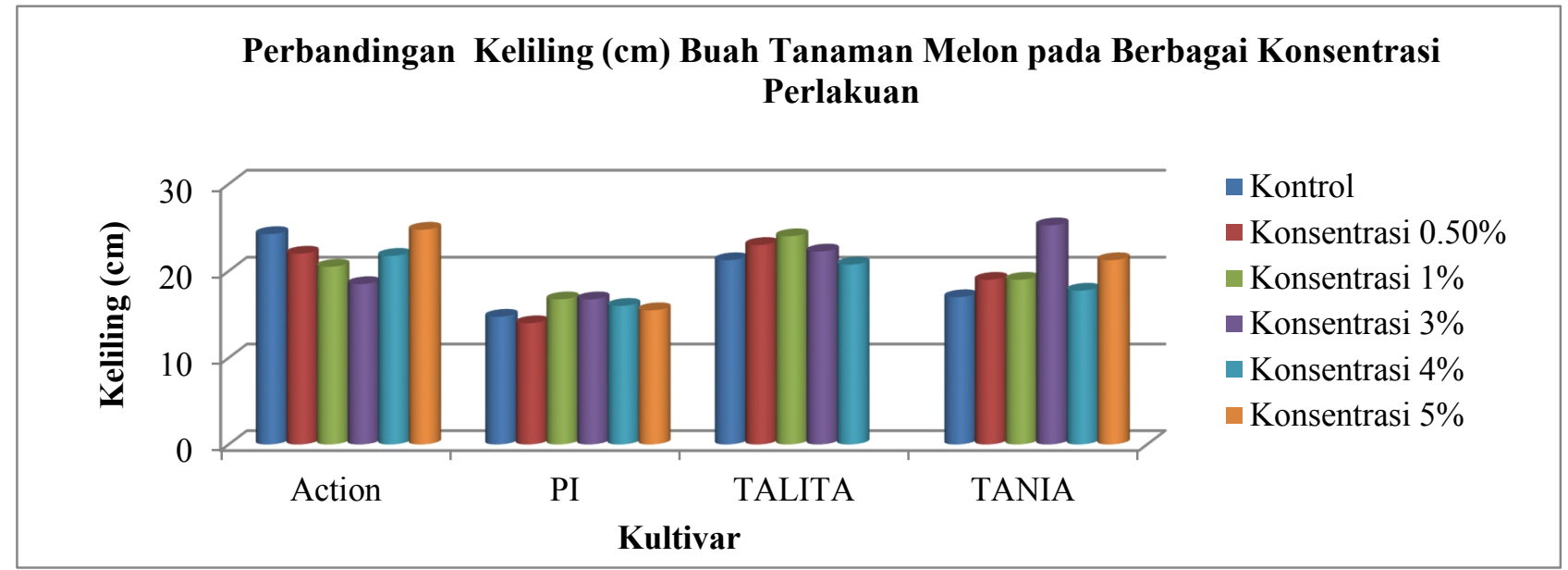

Gambar 2. Grafik perbandingan keliling buah melon TANIA dan TALITA

Gambar 2 menunjukkan bahwa keliling buah melon TANIA lebih rendah dibanding dengan indukan Action tetapi lebih tinggi dibanding dengan PI. Sedangkan keliling buah melon TALITA lebih tinggi dari indukan PI tetapi lebih rendah dari indukan Action.

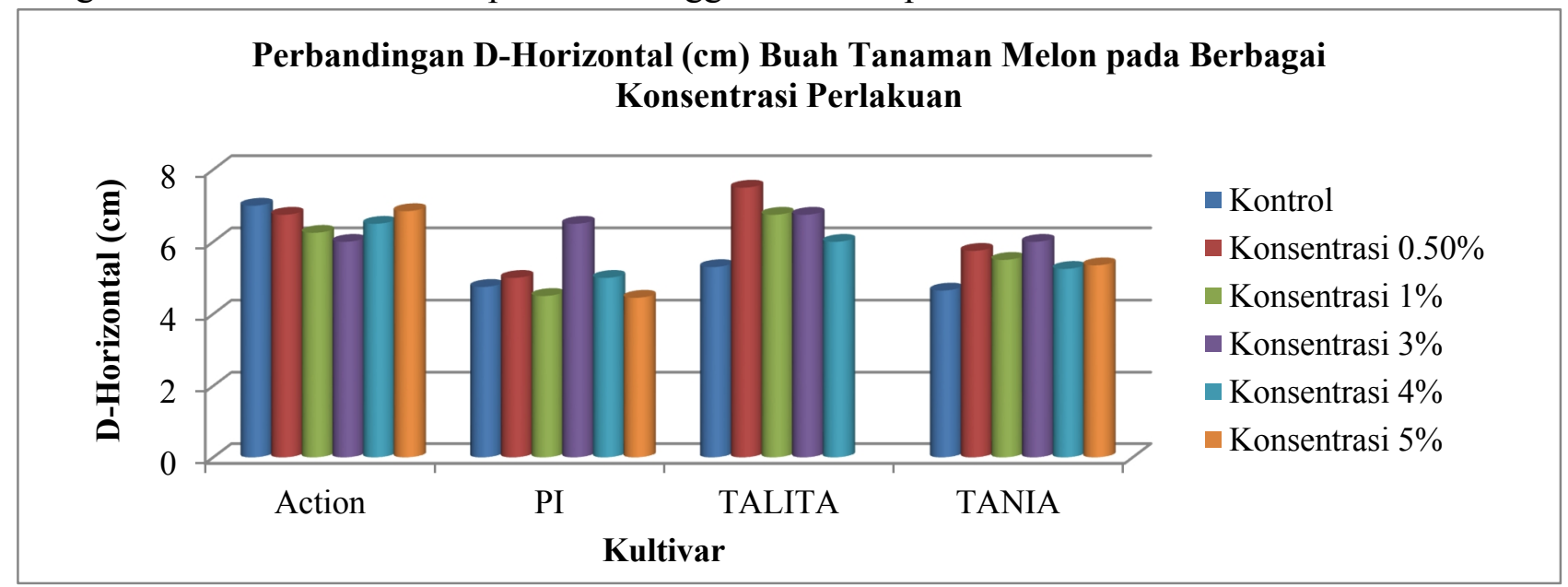

Gambar 3. Grafik perbandingan d-Horizontal buah melon TANIA dan TALITA 
Gambar 3. menunjukkan bahwa DHorizontal buah melon TANIA lebih rendah dibanding dengan indukan Action tetapi lebih tinggi dibanding dengan indukan PI.
Sedangkan D-horizontal buah melon TALITA lebih tinggi dari kedua indukannya yaitu Action dan PI.

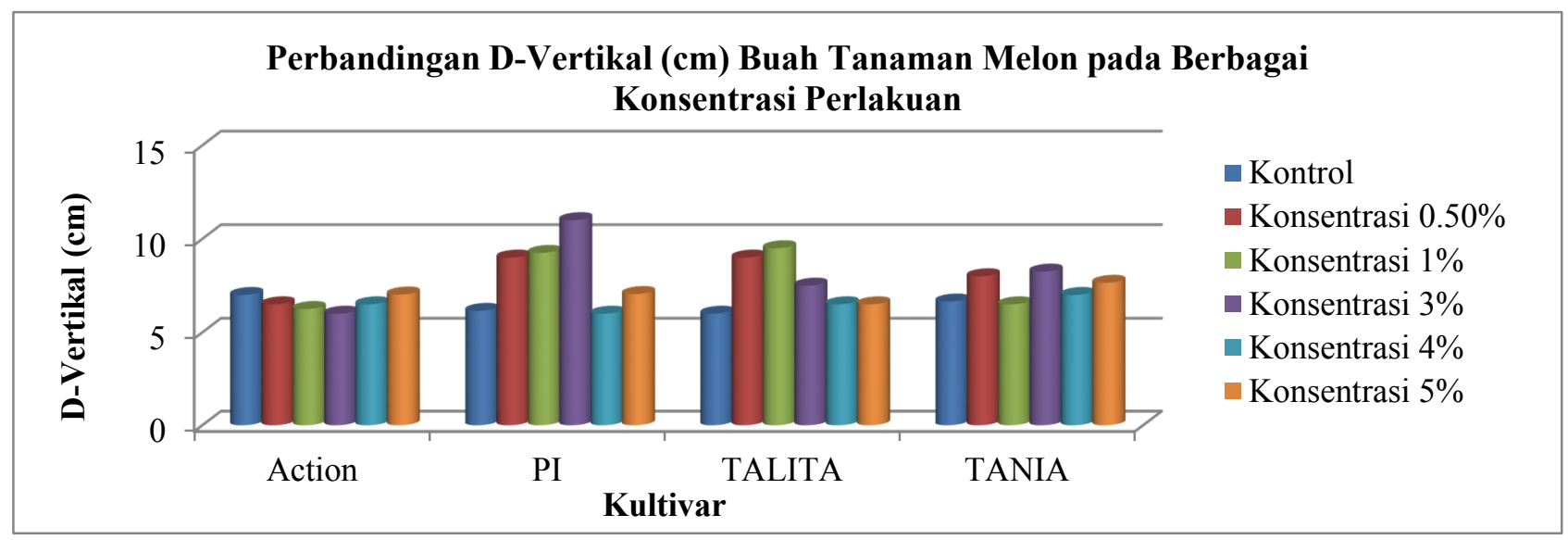

Gambar 4. Grafik perbandingan D-vertikal buah melon TANIA dan TALITA

Gambar 4. menunjukkan bahwa DVertikal buah melon TANIA lebih rendah dibanding dengan indukan PI dan lebih tinggi dibanding Action. Sedangkan D-vertikal buah melon TALITA lebih tinggi dari indukan Action tetapi lebih rendah dari indukan PI.

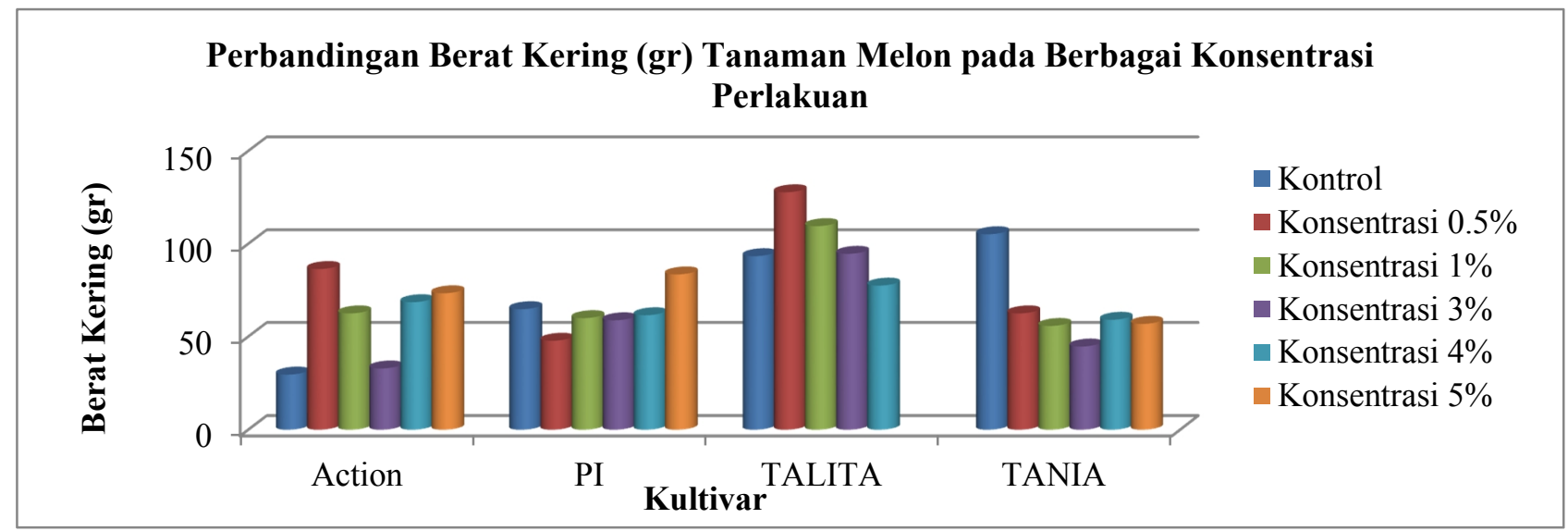

Gambar 5. Grafik perbandingan berat kering tanaman melon TANIA dan TALITA

Gambar 5. menunjukkan bahwa berat kering tanaman TANIA lebih rendah dibanding dengan indukan PI dan lebih tinggi dibanding Action. Sedangkan berat kering tanaman melon TALITA lebih tinggi dari kedua indukannya yaitu Action dan PI.

\section{PEMBAHASAN}

Lahan kritis karst merupakan lahan yang memiliki tekstur kering - cadas karena banyak mengandung $\mathrm{CaCO}_{3}$. Lahan ini miskin akan bahan organik dan unsur N, P, dan K. Tanah yang mengandung bahan organik umumnya bersifat asam. Kapur dalam tanah mempunyai asosiasi dengan keberadaan kalsium dan magnesium tanah. Hal ini karena keberadaan kedua unsur tersebut sering ditemukan berasosiasi dengan karbonat. Secara umum pemberian kapur ke tanah dapat mempengaruhi sifat fisik dan kimia tanah serta kegiatan jasad renik tanah. $\mathrm{CaCO}_{3}$ merupakan bahan kimia yang bersifat basa. Tanaman melon dapat hidup pada range $\mathrm{pH}$ 5.8-7.2. Pengapuran bertujuan untuk menetralkan keasaman tanah. Keberadaan $\mathrm{CaCO}_{3}$ kadar rendah dapat menetralkan tanah sehingga sesuai untuk ditanami melon. Namun, tanah yang memiliki kandungan $\mathrm{CaCO}_{3}$ yang tinggi, 
belum tentu tanah tersebut juga memiliki tingkat kesuburan yang tinggi dan justru bersifat toksik bagi tanaman karena $\mathrm{CaCO}_{3}$ akan menyerap unsur hara dari dalam tanah yang dibutuhkan tanaman untuk pertumbuhannya. Pada penelitian ini, diambil sampel tanah pada lahan dari tiga lokasi lahan kritis karst Yogyakarta, meliputi perbukitan Gunung Sewu, Kabupaten Gunung Kidul, Perbukitan Sentolo, Kabupaten Kulon Progo, dan Perbukitan Dlingo, Kabupaten Bantul.

Berdasarkan Tabel 1 dapat dilihat bahwa kandungan $\mathrm{CaCO}_{3}$ dari ketiga lokasi survey terdapat perbedaan. Pada lahan karst Dlingo, Kabupaten Bantul didapatkan kadar $\mathrm{CaCO}_{3}$ sebesar $0.85 \%$; pada lahan karst Sentolo, Kabupaten Kulon Progo didapatkan kadar $\mathrm{CaCO}_{3}$ sebesar 3.195\%; sedangkan pada lahan karst Gunung Sewu, Kabupaten Gunung Kidul didapatkan kadar $\mathrm{CaCO}_{3}$ sebesar 4.32\%.

Pada penelitian ini digunakan tanaman melon TACAPA x PI (TANIA) dan TACAPA $\mathrm{x}$ Action (TALITA). Melon TANIA merupakan melon hasil persilangan backcross TACAPA, yaitu persilangan dengan salah satu indukkannya yakni PI. Sedangkan melon TALITA merupakan melon hasil persilangan testcross TACAPA, yaitu persilangan dengan salah satu indukkannya yaitu Action. TACAPA sendiri merupakan melon unggul hasil persilangan antara PI dengan Action dengan testcross PI (Aristya, 2006; Qurrohman, 2008). Melon TANIA dan TALITA memiliki keunggulan tahan terhadap penyakit powdery mildew dan bila diproyeksikan dapat tumbuh di lahan karst. Kedua karakter fenotip tersebut merupakan sifat yang diwariskan dari tetuanya yaitu TACAPA. Penanaman tanaman melon dilakukan di greenhouse Kebun Pendidikan Penelitian Pengembangan Pertanian Universitas Gadjah Mada (KP4 UGM). Penanaman dilakukan di greenhouse karena kondisi lingkungan lebih terkontrol dan bebas dari adanya pollinator alami.

Ketahanan hidup tanaman melon TANIA dan TALITA terhadap kondisi lahan kritis karst dapat diketahui dengan mengamati morfologi pertumbuhan tanaman melon yang ditanam pada kondisi lahan karst selama beberapa minggu. Morfologi tanaman yang diamati meliputi tinggi tanaman, jumlah daun, jumlah bunga jantan, jumlah bunga betina, dan jumlah bunga lengkap. Pengamatan morfologi tanaman melon secara langsung bersifat kurang akurat dan lebih subjektif. Oleh karena itu, untuk lebih memastikan bahwa tanaman melon TANIA mampu tumbuh di lahan kritis, maka dilakukan analisis statistik dengan uji ANOVA menggunakan SPSS versi 15.0.

Berdasar hasil SPSS pada Tabel 2, terlihat bahwa tinggi dan jumlah daun tanaman melon TANIA dengan kedua indukkannya tidak berbeda nyata pada tiap konsentrasi. Hal ini menyatakan bahwa pertumbuhan tinggi dan pertambahan jumlah daun tanaman melon TANIA tidak terpengaruh oleh kondisi lahan karst (dapat tumbuh). Tinggi tanaman melon TALITA dengan kedua indukkannya tidak berbeda nyata pada tiap konsentrasi. Sedangkan pada jumlah daun tanaman melon TALITA dengan kedua indukannya tidak berbeda nyata pada konsentrasi $4 \%$. Namun, pada konsentrasi $0 \%, 0.5 \%, 1 \%, 3 \%$, dan $5 \%$ OTACAPA x $\lesssim$ Action tidak berbeda nyata dengan indukan Action tetapi berbeda nyata dengan indukan PI. Pada tabel 3 terlihat bahwa jumlah bunga jantan, jumlah bunga betina, jumlah bunga lengkap tanaman melon TANIA dan TALITA dengan kedua indukkannya tidak berbeda nyata pada tiap konsentrasi.

Selain dapat tumbuh pada lahan kritis karst, tanaman melon TANIA dan TALITA juga dapat menghasilkan keturunan berupa buah.Buah yang dihasilkan kemudian dianalisis pasca panen.Parameter yang diamati meliputi berat buah, keliling buah, diameter horizontal buah, diameter vertikal buah, dan berat kering tanaman. Data yang diperoleh kemudian disajikan dalam bentuk grafik.

Berdasarkan gambar grafik pada hasil, dapat dilihat bahwa buah tanaman melon TANIA lebih ringan dibanding dengan kedua indukkannya dan melon TALITA mempunyai berat buah lebih tinggi dari kedua indukannya.Buah tanaman melon TANIA lebih besar keliling dan diameter horizontalnya dibanding indukan PI tetapi lebih kecil dibanding indukan Action. Keliling buah tanaman melon TALITA lebih tinggi dari 
indukan PI tetapi lebih rendah dari indukan Actiondan D-horizontal buah lebih tinggi dari kedua indukannya. Diameter vertikal buah tanaman melon TANIA dan TALITA lebih besar dibanding indukan Action, tetapi lebih kecil dibanding indukan PI. Selain itu, dari grafik di atas juga terlihat bahwa berat kering tanaman melon TANIA lebih kecil dibanding dengan indukan PI dan lebih besar dibanding Action. Sedangkan tanaman melon TALITA mempunyai berat kering lebih tinggi dari kedua indukannya.Variasi data ini dapat disebabkan karena penyerapan nutrisi pada tanah yang tidak maksimal, sehingga buah yang dihasilkan pun tidak maksimal.

Pada penelitian ini, bila dilihat dari kedua indukannya, tanaman melon TANIA dan TALITA mewarisi sifat kedua indukannya.Hal ini dibuktikan dengan tanaman melon TANIA dan TALITA yang mampu tumbuh di kondisi lahan kritis karst seperti kedua indukannya yaitu PI dan Action. Selain itu tanaman melon TANIA dan TALITA juga dapat menghasilkan buah yang tidak kalah unggul terhadap kedua indukannya.

\section{KESIMPULAN}

Melon TANIA dan TALITA dapat tumbuh pada lahan kritis karst dalam berbagai konsentrasi perlakuan. Karakter fenotip pasca panen tanaman melon TANIA dan TALITA tidak jauh berbeda dengan karakter fenotip pasca panen yang dimiliki kedua indukannya.

Saran pada penelitian selanjutnya adalah perlu dilakukan uji multilokasi untuk mengetahui kemampuan adaptasi pertumbuhan tanaman melon TANIA dan TALITA di lahan karst sehingga melon ini mampu menjadi salah satu produk unggulan nasional.

\section{DAFTAR PUSTAKA}

Adams CR. and Early MP. 2004. Priciples of Horticulture. Great Britain: MPG Books. pp 203.

Aristya GN. 2009. Pewarisan dan Pemetaan Penanda Sifat Ketahanan Tanaman Melon Cucumis melo L.) Terhadap Jamur Tepung. [Skripsi]. Yogyakarta: Fakultas Biologi Universitas Gadjah Mada.
Aristya GN. 2012. Pengembangan Melon Unggul Tahan Penyakit dan Lahan Kritis Hasil Pemuliaan Tanaman. Proposal Intensif Riset Sinas. Yogyakarta: Fakultas Biologi Universitas Gadjah Mada.

Badan Litbang Pertanian Bagian Proyek Penelitian Terapan Sistem DAS Kawasan Perbukitan Kritis. 1997. Laporan Tahunan 1996/1997. Yogyakarta: Bagian Proyek Penelitian Terapan Sistem DAS Kawasan Perbukitan Kritis. hal 97.

Delaplane KS and Mayer DF. 2000. Crop Pollination by Bees. New York: CABI Publishing. pp 344.

Harjadi SS. 1989. Dasar-dasar Holtikultura. Bogor: Institut Pertanian Bogor Press. hal 506.

Karama AS and Abdurachman A. 1995. Kebijaksanaan Nasional Dalam Penanganan Lahan Kritis di Indonesia. Prosiding Lokakarya dan Ekspose Teknologi Sistem Usaha Tani Konservasi dan Alat Mesin Pertanian. 17-19 Januari 1995. Bogor: Pusat Penelitian Tanah dan Agroklimat. hal 1-6.

Mass AS, Nuryani dan Tukijo. 1995. Usaha penanganan lahan kritis bukit kapur Rongkop dan Kasihan, Yogyakarta (Suatu Tinjauan Empiris). Prosiding Lokakarya dan Ekspose Teknologi Sistem Usaha Tani Konservasi dan Alat Mesin Pertanian. 1719 Januari 1995. Bogor: Pusat Penelitian Tanah dan Agroklimat. hal 85-91.

Notohadiprawiro T. 1978. Lahan Sumber Daya atau Serba Gatra dan Lingkungan Hidup Manusia. Yogyakarta: Jurusan Ilmu Tanah Pertanian Universitas Gadjah Mada. hal 38.

Prajnanta F. 2006. Melon: Pemeliharaan Secara Intensif dan Kiat Sukses Beragribisnis. Jakarta: Penebar Swadaya. hal 163.

Prihatman K. 2000. Melon: Budidaya Pertanian. http://www.ristek.go.id. Diakses 7 September 2013.

Pusat Penelitian Tanah dan Agroklimat. 1993. Survei Tanah Detil di Sebagian Wilayah DI Yogyakarta (skala 1:50.000). Proyek LREP II, Part C. Bogor: Pusat Penelitian Tanah dan Agroklimat. hal 137. 
Richards AJ. 1997. Plant Breeding Systems. London: Chapman and Hall. pp 529.

Rubatzky VE and Yamaguci M. 1999. Sayuran Dunia 3: Prinsip, Produksi, dan Gizi. Bandung: Institut Teknologi Bandung. hal 292.

Rukmana R. 1994. Budidaya Melon Hibrida.
Yogyakarta: Kanisius. hal 73.

Schultheis JR. 2007. Muskmelon (Cantaloupes). http://www.ces.neese.edu.com. Diakses 30 Mei 2013.

Setiadi dan Parimin. 2006. Bertanam Melon. Jakarta: Penebar Swadaya. hal 96. 